\title{
Co-word analysis and academic performance from the Australasian Journal of Educational Technology in Web of Science
}

\author{
Jesús López-Belmonte, Antonio-José Moreno-Guerrero, Santiago Pozo-Sánchez, José-Antonio \\ Marín-Marín \\ Department of Didactics and School Organization, Faculty of Education, Economics and Technology, \\ University of Granada, Spain
}

\begin{abstract}
Since its inception in 1985, the Australasian Journal of Educational Technology (AJET) has been dedicated to the diffusion of studies on the integration of technology in higher education. Its track record in this field has placed it in the first quartile of the Scimago Journal $\&$ Country Rank. The objective of the study was to reveal to the scientific community the journey and evolution that this journal has had throughout its existence in Web of Science. A bibliometric methodology was used, supported by a scientific mapping from a unit of analysis of 798 documents. For this reason, a co-word analysis can be a fundamental tool for understanding the characteristics of their production and their impact on the scientific community. There is an evident progressive evolution of the studies published in the Australasian Journal of Educational Technology, with a first phase focused on the design and implementation of educational technology in learning environments, a second phase focused on the enrichment of technology and its acceptance within the processes of teaching and learning, and finally a stage focused on student and teacher perceptions of the implementation of technology in the educational context.
\end{abstract}

Implications for practice or policy:

- We have established a contextual framework to show researchers current trends in educational technology and delineate future lines of research.

- Those interested in this subject will have a set of bibliometric indicators to delve into the field of educational technology.

- Higher education teachers and students will discover the evolution of the use of technology in learning spaces.

Keywords: bibliometric analysis, scientific mapping, Australasian Journal of Educational Technology (AJET), SciMAT, Web of Science

\section{Introduction}

Bibliometric research applied to the analysis of scientific journals constitutes a fundamental tool for determining the characteristics of their production and their impact on the scientific community (AntaCabreros, 2008; Ariza \& Quevedo-Blasco, 2013). The publication of the results of an investigation in specialised journals is the fundamental step in disseminating the main findings of a field of knowledge (Bueno \& Fernández, 2003; Laufer, 2007). These scientific publications are the subject of bibliometrics (Pérez-Matos, 2002), which defines the processes of the science of literature and its disciplines based on counting and analysing techniques typical of statistics and mathematics (Pritchard, 1969).

Chen et al. (2019) consider that a systematic analysis of scientific publications on a certain topic provides insight into the state of its recent development. As a statistical method to evaluate scientific publications effectively, bibliometric analysis has been widely used to obtain this insight in various interdisciplinary fields. Some examples are the recent state of diabetes research in China (Chen, Weng et al., 2017), the scientific development of artificial intelligence in education (Moreno-Guerrero et al., 2020), the field of natural language processing (Chen, Chen et al., 2017) and the term equity in education (Jurado de los Santos et al., 2020).

Other research is related to the development of the technological pedagogical content knowledge (TPACK) model (Soler-Costa et al., 2021), the evolution of the literature on autism and parental influence (CarmonaSerrano et al., 2021), artificial intelligence in electronic health records research (Chen, Liu et al., 2018), 
research on technology-assisted language learning (Chen, Hao et al., 2018) and advances on Arduino in scientific research (López-Belmonte et al., 2020). Bibliometrics has been used not only to analyse particular topics such as those mentioned but been used to analyse journals and their impact and significance in the research community (Cascón-Katchadourian et al., 2020; Donthu et al., 2021).

In this way, the present study analysed the scientific literature of the Australasian Journal of Educational Technology (AJET) indexed in the Web of Science $(\mathrm{WoS})$ database from a bibliometric approach of mapping the co-words to obtain their production indicators and their structural and dynamic development from the constructs extracted from their publications.

Since its inception in 1985, AJET has been the international journal of the Australasian Society for Computers in Learning in Tertiary Education, whose main objective is to promote research and studies on the integration of technology in higher education, promote effective practice and influence policy. The journal is indexed in the Scopus database, appearing in Journal Citation Reports (JCR) in the second quartile (Q2) and in Scimago Journal \& Country Rank in the first quartile (Q1). The studies published by AJET have a high impact, obtaining a value of 44 in the h-index. The two most cited articles in the journal (Kennedy et al., 2008; McLoughlin \& Lee, 2010) have more than 783 citations combined. In this way, the bibliometric study of its production becomes fundamental for knowing in a global way the evolution of the journal during its first 35 years of productivity, through research and review articles on educational technology, information and communication technologies for education, online learning and e-learning, educational design, multimedia, computer-aided learning and related areas. Reviewing articles published in the journal can provide an overview of trends in scientific research as well as identify emerging issues within the field of educational technology; in particular, it can provide a better understanding of what has been researched and, in addition, make predictions about what will happen in the future (Morris et al., 2002).

The main topics addressed by AJET include studies that promote the understanding of educational technology in post-secondary education settings, including higher and continuing education and lifelong learning and training. Therefore, manuscripts that develop experiences in school stages are excluded. In short, AJET addresses a set of topics related to the advances in knowledge of educational technology in the field of post-school education, which are of enormous interest to both the scientific community and the teaching community - all of this in order to offer the latest advances and innovations in the development of technology in education.

\section{Justification and objectives}

This study analysed the scientific literature of AJET. The journal currently presents prestigious indexation, such as the JCR with an impact factor of 1396 and Scopus (CiteScore = 3.5; CiteScoreTracker = 5.3). There are already several bibliometric studies carried out on AJET (Bond, 2018; Bond \& Buntins, 2018). However, as a novelty, we used a scientific mapping of co-keywords, catalogued as a bibliometric technique that takes into account the measurement of various production indicators and the structural and dynamic development of the constructs extracted from the publications (López-Robles et al., 2019).

To follow a research model validated by the scientific community, this research adhered to the guidelines and analytical processes carried out by other impact studies that have analysed the state of a question in the scientific literature of WoS (Carmona-Serrano et al., 2021; Mac Fadden et al., 2020).

Specifically, the general objective of this research was to inform the scientific community about its journey and evolution throughout its existence in WoS. To achieve this objective, we present the following specific objectives, which will guide the reader through the entire investigative process:

- determine the number of publications in and annual citations of AJET during the time period established in the study

- determine the most prolific institutions, authors and countries as well as the most cited articles in AJET during the chosen time interval

- discover the connections established between countries and institutions in AJET publications

- determine the evolution of keywords and themes in AJET according to the time period established 
- estimate the next trends in the field of research in AJET

- identify the most prolific authors and themes as well as the connections between authors in the time period analysed in the study.

\section{Method}

\section{Research design}

This study was based on the principles of bibliometrics by which different actions are performed in order to search, register, analyse and predict scientific literature (López-Belmonte et al., 2019; Martínez et al., 2015). To carry out each of these processes, we followed the guidelines of experts in the field of scientometry (Montero-Díaz et al., 2018).

Among the analytics addressed, this work includes an analysis of the performance of the reported publications, of the established collaborations, of a co-word analysis (Hirsch, 2005) and of various bibliometric indicators (indexes h, g, hg, q2) (Cobo et al., 2011). This was done to generate maps with nodes that reveal the performance and location of various conceptual subdomains (López-Belmonte et al., 2020) concerning AJET. Moreover, we expected the different processes carried out to establish the thematic development of the journal (López-Robles et al., 2019).

\section{Procedure}

All research requires the implementation of different actions to achieve its objectives. In this case, the study was carried out in different phases (Moreno-Guerrero et al., 2020).
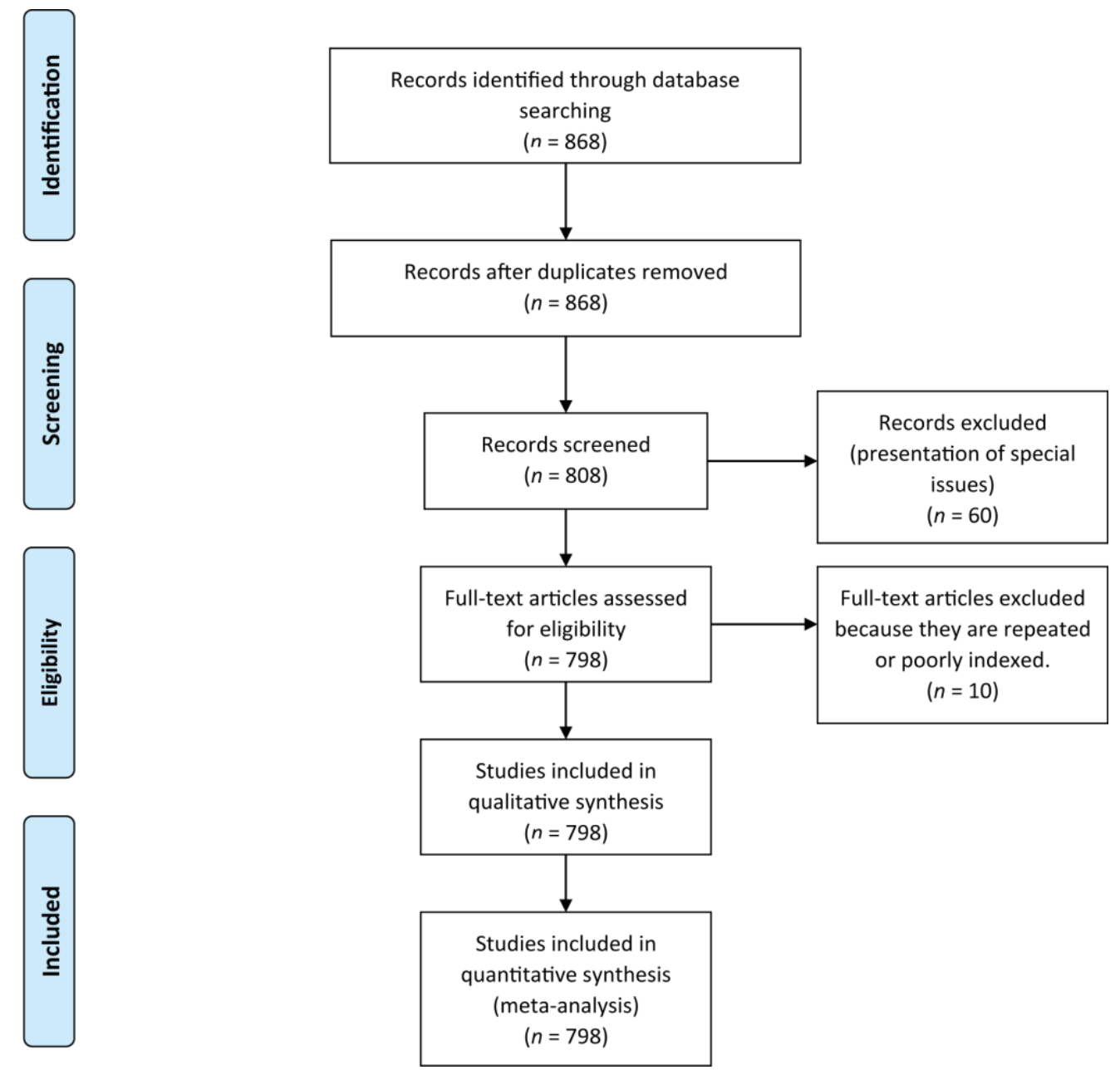

Figure 1. Flow chart according to the PRISMA protocol 
First, the database was selected. In this case, it was WoS, because it contains a large volume of impact publications related to social sciences, the field of knowledge that AJET houses, and the database from which JCR draws to establish a ranking. Next, all the publications indexed under the metadata "Australasian Journal of Educational Technology" were reported. This search yielded a total of 868 documents. The first AJET publications indexed in WoS refer to the year 2007. For this reason, this work covers 13 years (20072020).

To refine the results obtained, a series of criteria were applied (López-Belmonte et al., 2021). As exclusion criteria, publications classified as editorials or presentations of special issues in the journal were taken into account $(n=70)$, and the year 2021 was suppressed, as the year was not completed. Manuscripts published in the journal and that were indexed in WoS in or prior to 2020 were included. The following were also considered for inclusion: institutions ( $x \geq 22)$, authors $(x \geq 20)$, countries $(x \geq 50)$ and the five most cited manuscripts.

Taking into account the defined criteria, a final analysis unit of 798 publications resulted. At all times, we followed the guidelines and actions established by the protocol of the preferred reporting items for systematic reviews and meta-analyses (PRISMA) matrix (Moher et al., 2015) (see Figure 1).

\section{Data analysis}

We used Various programs to analyse AJET: the Analyse Results and Creation Citation Report applications established by WoS on its platform, the VOSviewer software to generate a map of collaborations between countries and institutions and SciMAT to carry out a longitudinal study on the structural and dynamic development of scientific production. For this, we followed the guidelines of experts in this tool (MoralMuñoz et al., 2020). Likewise, we carried out a co-word analysis at the thematic level in several phases:

- Recognition: In this phase, the keywords of the reported documents were analysed $(n=1170)$. A map of co-occurrence nodes was generated. A normalised network of co-words was developed. The most significant keywords were detected $(n=1029)$. The most decisive themes and concepts were represented by a clustering algorithm.

- Reproduction: A strategic diagram and a thematic network were developed based on the principles of centrality and density. In the graphic analysis made, four distinct regions were established: (a) upper right: relevant themes; (b) top left: deep-rooted and isolated issues; (c) lower left: issues in disappearance or projection; (d) lower right: themes of little development and transversal.

- Determination: The evolution of nodes was analysed in the different periods or established time intervals. In this research, three periods were configured $(\mathrm{P} 1=2007-2011$; P2 $=2012-2016$; P3 $=2017-2020)$. These periods were thus configured to achieve an equitable volume in scientific production ( $\mathrm{P} 1=271$ documents; $\mathrm{P} 2=285$ documents; $\mathrm{P} 3=242$ documents). Therefore, the time periods were set in this particular way. In this step, the strength of association was calculated through the volume of keywords in common between the different periods. For the analysis of the authors, all the publications were grouped under the same period that entails the time span that was the focus of our study $(\mathrm{Px}=2007-2020)$.

- Performance: In this phase, different production indicators were taken into consideration with their corresponding inclusion criteria (Table 1).

Table 1

Production indicators and inclusion criteria

\begin{tabular}{ll}
\hline Configuration & Values \\
\hline Analysis unit & Keywords authors, keywords WoS \\
Frequency threshold & Keywords: $\mathrm{P}_{1}=(2), \mathrm{P}_{2}=(2), \mathrm{P}_{3}=(2) ;$ Authors: $\mathrm{P}_{\mathrm{x}}=(2)$ \\
Network type & Co-occurrence \\
& Keywords: $\mathrm{P}_{1}=(1), \mathrm{P}_{2}=(1), \mathrm{P}_{3}=(2)$ \\
Co-occurrence union value threshold & Authors: $\mathrm{P}_{\mathrm{x}}=(2)$ \\
& Equivalence index: eij = cij2 / Root (ci - cj) \\
Normalisation measure & Maximum size: $9 ;$ Minimum size: 3 \\
Elustering algorithm & Jaccard index \\
Ovolutionary measure & Inclusion rate \\
\hline
\end{tabular}




\section{Results}

\section{Scientific performance and production}

The total scientific production volume of AJET in WoS is 798. From its beginning in the WoS database in 2007 until 2020, its production, in terms of volume, has remained constant and continuous. The year 2012 is the most outstanding, recorded the highest volume of production. This trend was not observed in the number of citations, which totalled 11,332. This volume of citations began to rise sharply in 2009 and remained constant and rising until 2017. The number of annual citations fell slightly in 2018 and rose again in 2019 and 2020. The year with the highest volume of citations is 2020 (Figure 2).

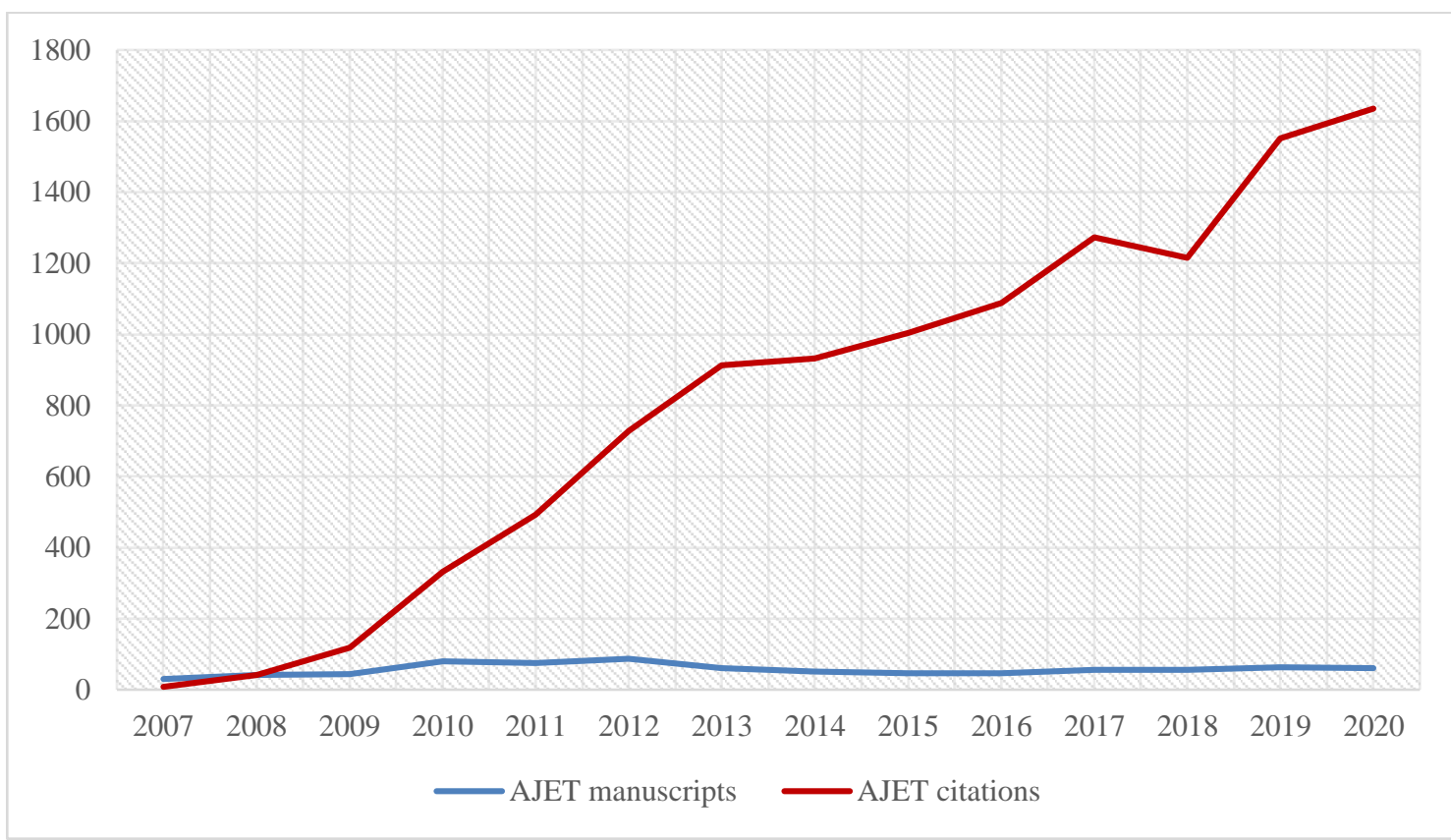

Figure 2. Evolution of scientific production

Analysing the institutions that publish the most in AJET, Nanyang Technological University stands out in terms of the number of manuscripts. In addition, it has the highest h-index volume. Furthermore, the University of Melbourne has the highest number of citations, although its production volume and h-index are lower. With respect to authors, three have a higher volume of production than the rest: Atkinson, Dalgarno and Henderson. It is noteworthy that McLoughlin has a lower volume of production than the other authors, although her citation level is much higher, with a total volume of 331. In addition, it should be noted that her h-index in AJET is 2; therefore, she has only one highly cited manuscript, while the rest have a very low citation volume. In relation to countries, Australia stands out as the country with the most contributions in AJET, coinciding with the highest number of citations and the highest h-index (Table 2). 
Table 2

Most prolific institutions, authors and countries

\begin{tabular}{lccc}
\hline Institutions & TP & TC & H \\
\hline Nanyang Technological University & 41 & 892 & 15 \\
Monash University & 35 & 403 & 11 \\
University of Melbourne & 28 & 916 & 12 \\
Griffith University & 24 & 851 & 10 \\
Education University of Hong Kong & 23 & 368 & 11 \\
National Taiwan Normal University & 23 & 227 & 8 \\
University of Technology Sydney & 22 & 159 & 9 \\
\hline Authors & TP & TC & H \\
\hline Atkinson, R. (Independent researcher) & 25 & 2 & 2 \\
Dalgarno, B. (Charles Sturt University) & 24 & 62 & 3 \\
Henderson, M. (Monash University) & 24 & 71 & 3 \\
McLoughlin, C. (Australian Catholic University) & 21 & 331 & 2 \\
\hline Countries & TP & TC & H \\
\hline Australia & 336 & 5120 & 31 \\
Taiwan & 102 & 1469 & 23 \\
China & 70 & 888 & 16 \\
United States of America & 70 & 734 & 15 \\
\hline
\end{tabular}

Note: TP: article count; TC: citation count; H: Hirsch index.

In relation to countries, five clusters are mainly collaborative, and the one that is the central axis of all collaboration is Australia, which stands out for its volume of production in AJET. By volume of collaboration, Australia is related mainly to the United States of America and England (Figure 3).

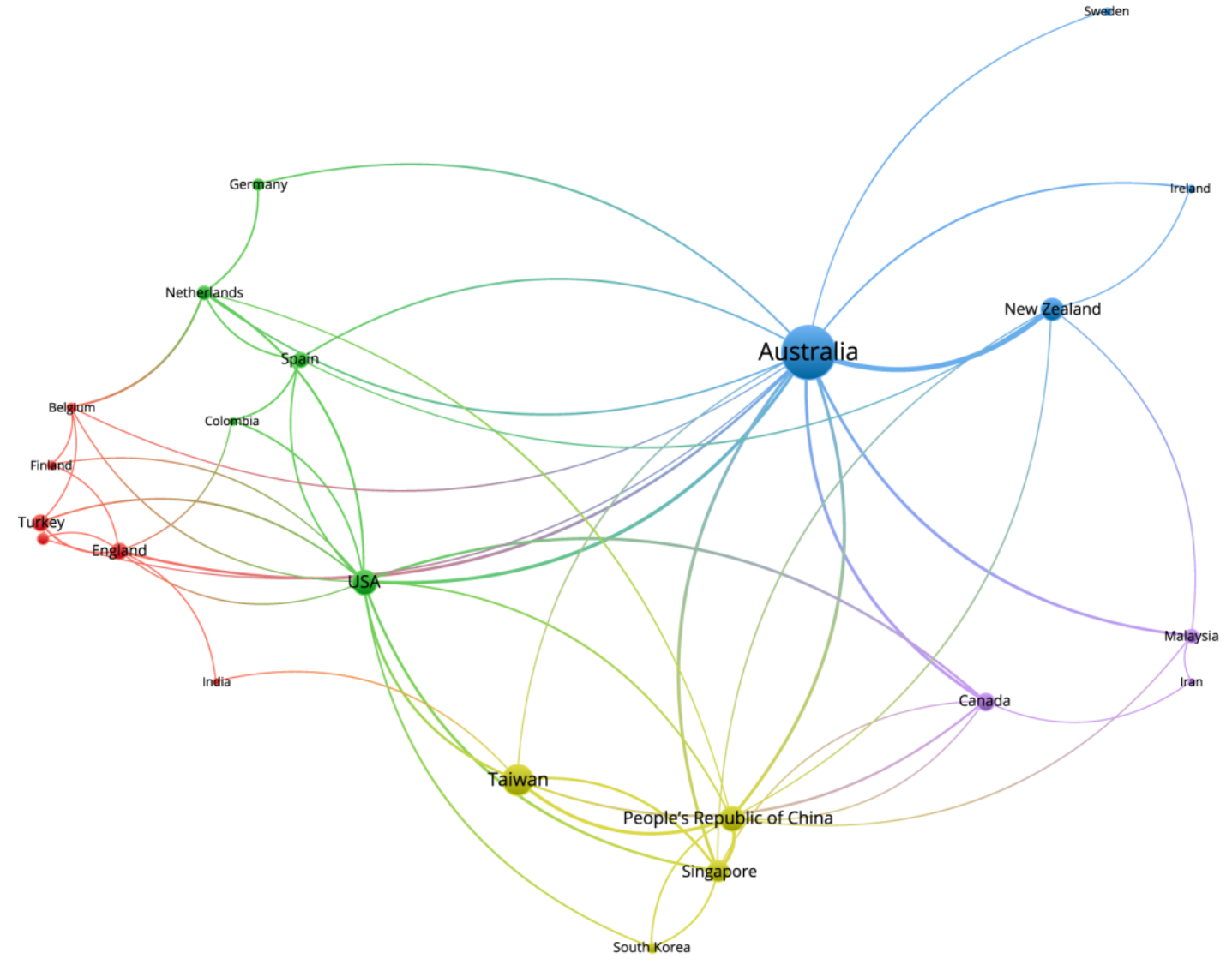

Figure 3. Collaboration between countries 
Collaborations between institutions are evenly distributed, with no institutions standing out above others. There are four collaboration clusters, of which the one established by Griffith University stands out due to the number of collaborations. Furthermore, this cluster is the central axis of collaboration, given that it collaborates with the other established clusters (Figure 4).

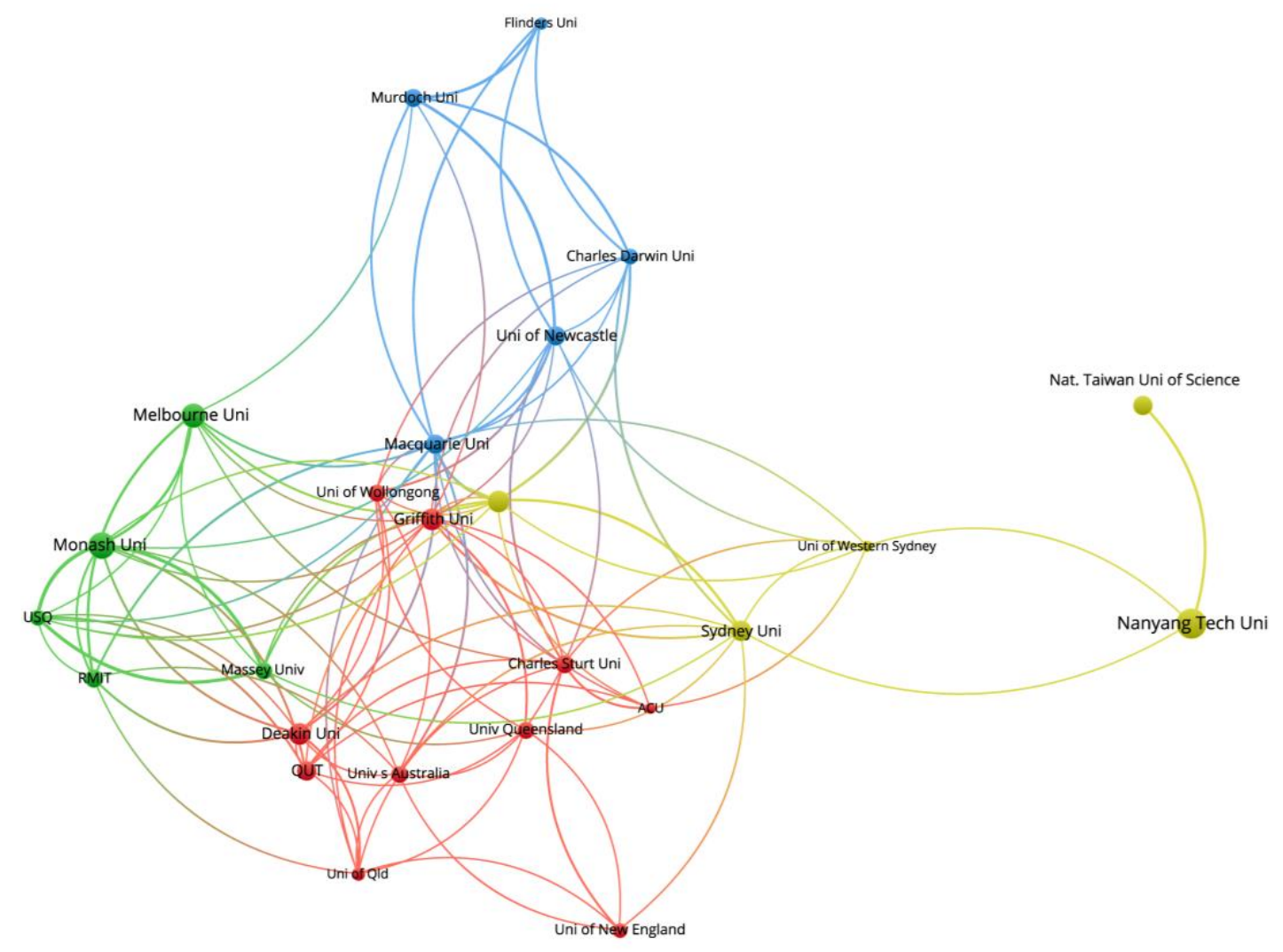

Figure 4. Collaboration between institutions

In relation to the most cited manuscripts in AJET, the study carried out by Kennedy et al. (2008) stands out, with 440 citations. This quantitative study had several objectives: It analysed the extent to which university students use technology, their degree of use in the educational sphere, as well as their relationship with their daily lives. The results of this study show that students tend to be very familiar with technological resources and devices, although with different degrees of familiarity. Another study that stands out for its volume of citations is the one by McLoughlin and Lee (2010, with 329 citations. The general objective of this research was to analyse the state of the art in the literature on personalised and self-regulated learning through digital tools that incorporate social software. Among the various results obtained, the fact that social computing technologies require more personal, social and participatory pedagogies stands out. Also notable, with 155 citations, is the study carried out by Irwin et al. (2012). Using a quantitative approach, this study analysed students' perceptions of Facebook as a social network for disseminating academic information and fostering interaction among students. The results reveal that Facebook contributes to facilitating collaborative and cooperative learning. However, the authors stated that more research is needed on how learning outcomes improve. Another outstanding study is that of McGarr (2009), with 153 citations. McGarr carried out a literature review of the state of the art and analysed the educational use of podcasting in college, as well as whether it allows flexibility and mobility in learning and its influence on traditional lecture. The results reflect the benefits of podcasting to improve learning, but its use should be taken with caution, since the results may vary depending on whether podcasting is used as a complement to learning or as a base. Finally, with 137 citations, is the quantitative study carried out by Elgort et al. (2008). The study analysed the perceptions of students and teachers of the use of wikis to carry out group projects in higher education. The results show how both educational agents position the wiki as a tool that encourages collaboration. All these studies are based on technological resources applied to the field of education. 
Table 3

Most cited articles

\begin{tabular}{|c|c|c|c|}
\hline Authors & Year & Title & Citations \\
\hline $\begin{array}{l}\text { Kennedy, G. E., Judd, T. S., } \\
\text { Churchward, A., Gray, K., \& } \\
\text { Krause, K. L. }\end{array}$ & 2008 & $\begin{array}{l}\text { First year students' experiences } \\
\text { with technology: Are they really } \\
\text { digital natives? }\end{array}$ & 440 \\
\hline McLoughlin, C., \& Lee, M. J. W. & 2010 & $\begin{array}{l}\text { Personalised and self regulated } \\
\text { learning in the Web } 2.0 \text { era: } \\
\text { International exemplars of } \\
\text { innovative pedagogy using social } \\
\text { software }\end{array}$ & 329 \\
\hline $\begin{array}{l}\text { Irwin, C., Ball, L., Desbrow, B., } \\
\text { \& Leveritt, M. }\end{array}$ & 2012 & $\begin{array}{l}\text { Students' perceptions of using } \\
\text { Facebook as an interactive learning } \\
\text { resource at university }\end{array}$ & 155 \\
\hline McGarr, O. & 2009 & $\begin{array}{l}\text { A review of podcasting in higher } \\
\text { education: Its influence on the } \\
\text { traditional lecture }\end{array}$ & 153 \\
\hline $\begin{array}{l}\text { Elgort, I., Smith, A. G., \& Toland, } \\
\text { J. }\end{array}$ & 2008 & $\begin{array}{l}\text { Is wiki an effective platform for } \\
\text { group course work? }\end{array}$ & 137 \\
\hline
\end{tabular}

\section{Structural and thematic development}

Figure 5 provides relevant data on the keywords and their evolution over the set time periods. Among the information it provides are the number of keywords that are no longer present in the next period (represented with an arrow pointing upwards and in an oblique position) and the keywords that are newly included in a new period (represented with an arrow pointing downwards and in an oblique position). It also shows the keywords that exist in a given period (represented within a circumference) and the percentage match of keywords between periods (represented with a horizontal arrow pointing to the right). In this case, the percentage of coincidence between the established time periods is high, being higher between the second and third period (with 53\% coincidence) than between the first and second periods (with $44 \%$ coincidence). This indicates that AJET presents a well-established and consolidated line of research over time. The manuscripts in the journal are based on clearly defined topics. In addition, the number of keywords used by the authors increases over time. In other words, in recent times, authors have been making greater use of keywords. Although the number of manuscripts is even over the established periods, the number of keywords is not.

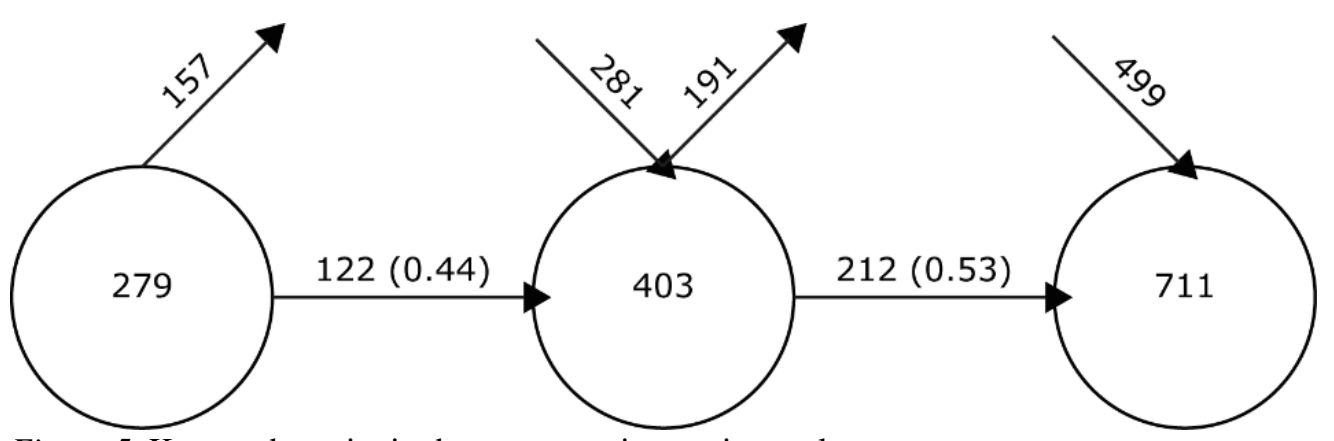

Figure 5. Keyword continuity between contiguous intervals

The academic performance and the interval diagram show relevant values for each of the established periods. On the one hand, the academic performance provides data on the most relevant bibliometric indicators of the topics resulting from the co-word analysis. These bibliometric indicators are the h-index, the g-index, the hg-index and the q2-index. Moreover, the temporal diagram provides data on the value and level of importance of the topics resulting from the analysis. The indicator used to obtain the values in the temporal diagram is the Callon index, which is based on centrality and density. Centrality provides information on the strength of the external links established between the various themes or keywords. Density provides information on the strength of the internal links generated for each keyword. These data show the degree of development of the journal's themes in the established time periods. 
Starting with the various analyses, Figure 6, corresponding to the period 2007-2011, shows that the theme with the highest bibliometric value is "design", closely followed by "technology" and "teachers". Of all the themes resulting from the analysis, "environments", "attitudes", "knowledge", and "design" stand out, which are considered to be driving themes. Analysing in more detail, it can be seen that:

- "environments" is related to "discovery", "prompts", "language", "satisfaction", "performance", "ICT", "generating-cognitive-activity" and "problem-solving-processes"

- "attitudes" is related to "acceptance", "user-acceptance", "information-technology", "issues", "management-system", "self-efficacy", "technology-integration" and "information"

- "knowledge" is related to "discourse", "patterns", "computer-games", "classroom", "framework", "styles", "participation" and "impact"

- "design" is related to "on-line", "integration", "community", "model", "system", "highereducation", "cognitive-load" and "split-attention".
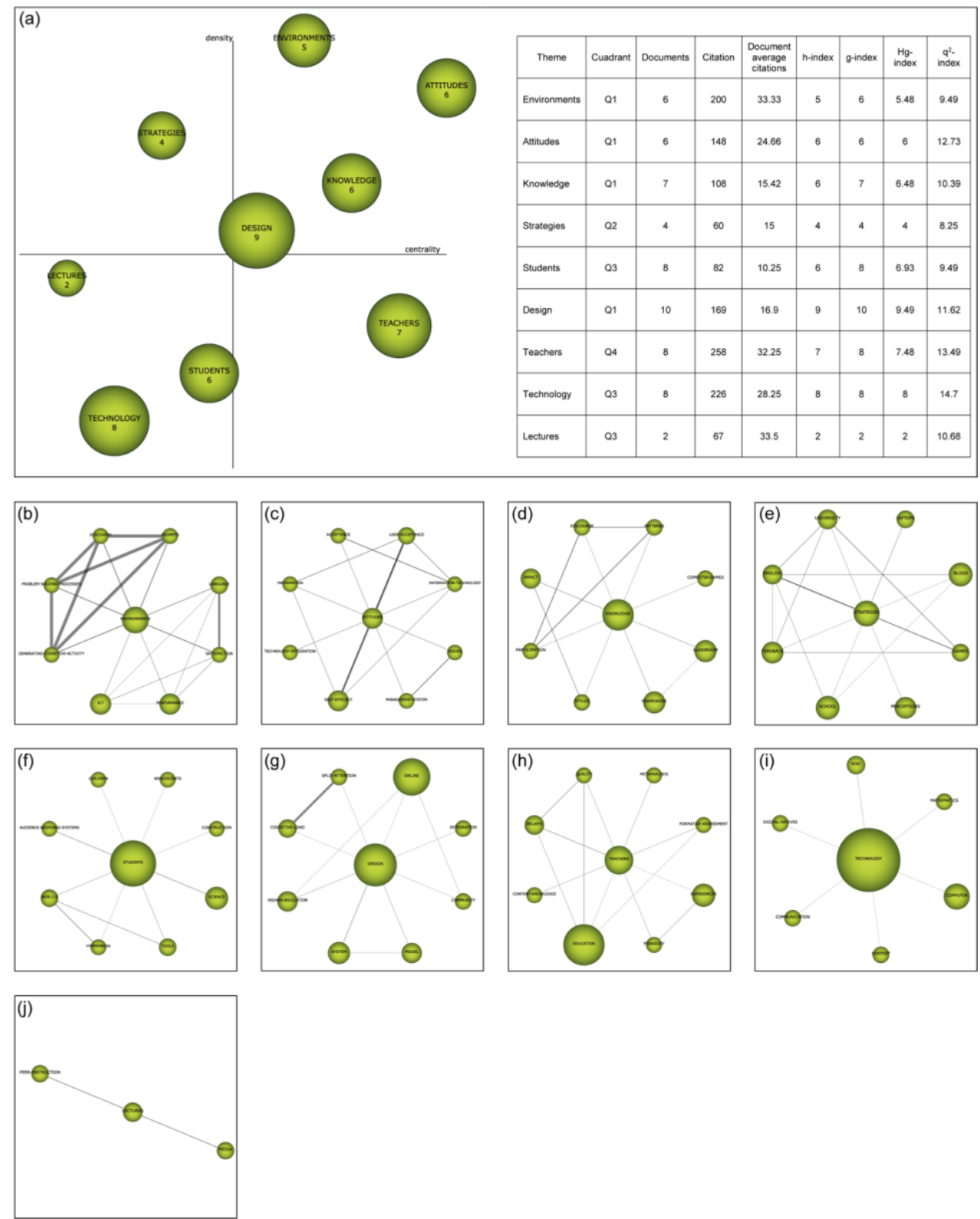

Figure 6. (a) Strategic diagram (h-index) and performance from 2007 to 2011. Themes are shown as follows: (b) "environments"; (c) "attitudes"; (d) "knowledge"; (e) "strategies"; (f) "students"; (g) "design"; (h) "teachers"; (i) "technology"; (j) "lectures". 
In the "environments" theme, strong connections between the "prompts", "discovery", "problem-solvingprocesses", and "generating-cognitive-activity" themes can be observed, which shows the strong relationship within this theme and the trend within this cluster. In "attitudes", there is a strong relationship with "user-acceptance" and "self-efficacy". In "knowledge", no research trend is more pronounced than another. The term "design" appears to be more related to the themes "split-attention" and "cognitive-load". All these data indicate that, in this period, the research was focused on learning environments and the attitudes of students in the application and use of technological resources during the teaching and learning processes. It also focused on the knowledge acquired by the students themselves while using technological resources during their learning, and on the design of the training processes in which the technological resources are applied.
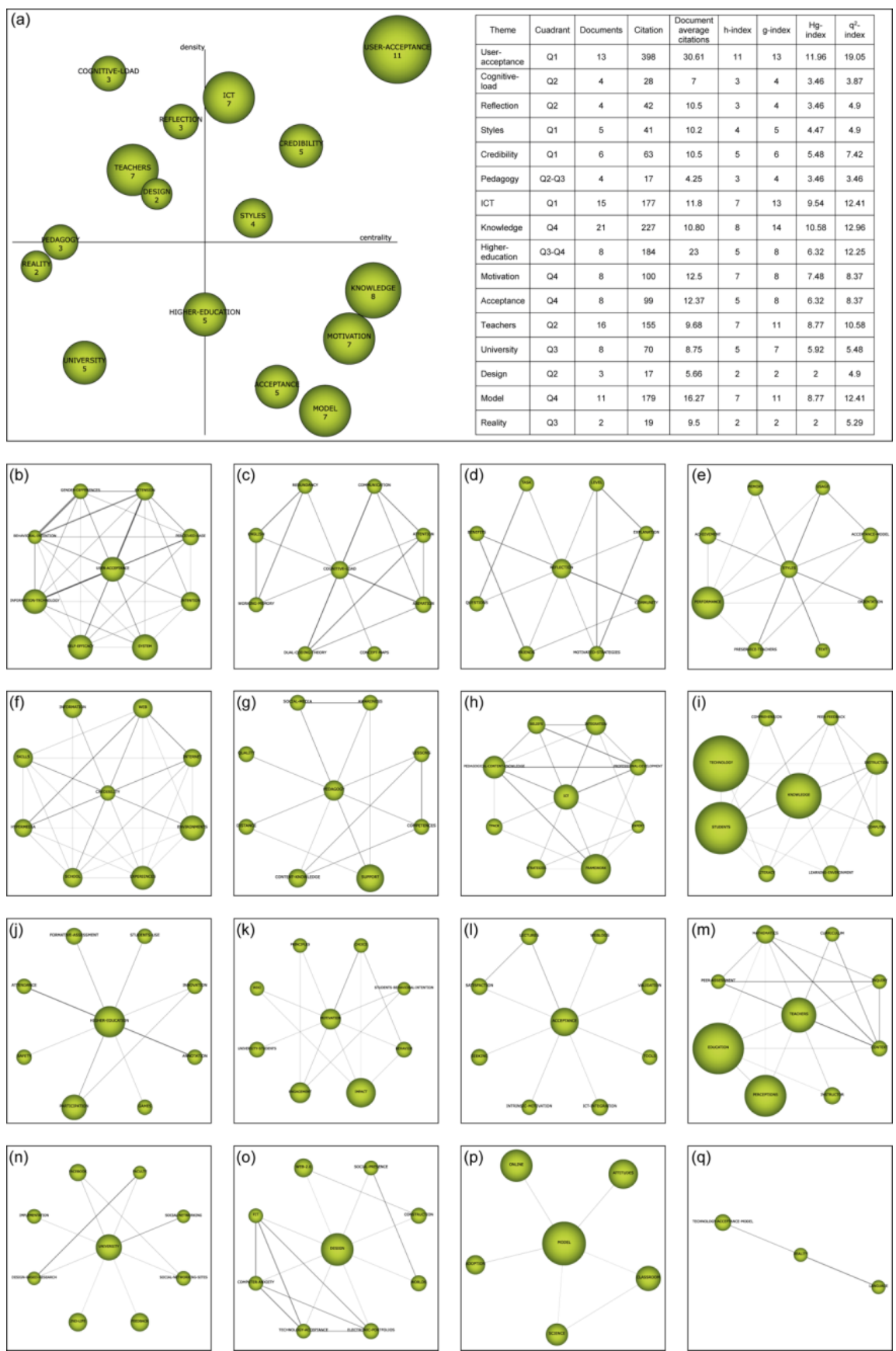

Figure 7. (a) Strategic diagram (h-index) and performance from 2012 to 2016. Themes are shown as follows: (b) "user-acceptance"; (c) "cognitive-load"; (d) "reflection"; (e) "styles"; (f) "credibility"; (g) "pedagogy"; (h) "ICT"; (i) "knowledge”; (j) "higher-education"; (k) "motivation"; (l) "acceptance”; (m) "teachers"; (n) "university"; (o) “design"; (p) "model”; (q) "reality". 
In the second time interval, between 2012 and 2016 inclusive, "user-acceptance" is shown as the subject with the highest bibliometric performance, being quite distant from the rest of the subjects. In this period, "user-acceptance", "ICT", "credibility", and "styles" are the driving themes. The analysis shows that:

- "user-acceptance" is most directly related to "gender-differences", "extension", "perceived-ease", "intention", "system", "self-efficacy", "information-technology" and "behavioural-intention"

- "ICT" is most directly related to "beliefs", "integration", "professional-development", "expert", "framework", "strategies", "TPACK” and "pedagogical-content-knowledge"

- "credibility" is most directly connected with "information", "web", "internet", "environments", "experience", "school", "hypermedia" and "skills"

- "styles" is most directly connected with "memory", "usage”, “orientation”, "text”, "preserviceteachers", "performance" and "achievement".

With regard to the thematic area "user acceptance", a more pronounced trend can be observed with research related to "behavioural-intention" and "gender-differences". With the thematic "ICT", a more pronounced tendency is shown with the research related to "professional-development", "pedagogical-contentknowledge" and "framework". With the themes "credibility" and "styles", there is no strong trend in the research on this cluster. These data indicate that the research was oriented mainly towards the acceptance of students and teachers in the use of information and communication technologies in educational processes, the analysis of possible gender differences in the use of pedagogical technological resources, the pedagogical training of teachers in the use and application of technological resources in teaching and learning processes, the credibility of the devices and applications used in the pedagogical act and the pedagogical methods used by teachers in the use of technological resources (Figure 7).

In the last established time interval (2017-2020), the subject with the highest academic performance is "perceptions", although it stands out slightly from the rest, given that the subjects "informationtechnology", "motivation", "higher-education", "framework", "attitudes", and "technology" are one step below. In this period, the themes considered as driving forces are "information-technology", "framework", and "motivation". Analysing each of them in more depth, it seems that:

- "information-technology" is directly related to "unified-theory", "services", "perceivedusefulness", "model", "acceptance", "adoption", "user-acceptance" and "extension"

- "framework" relates to "instructional-design", "validation", "research-trends", "computer", "preservice-teachers", "TPACK”, "pedagogical-content-knowledge" and "quality"

- "motivation" relates to "collaboration", "case-study", "predictors", "behaviour", "moocs", "strategies", "students" and "performance".

With regard to the theme "information-technology", no research trends are more relevant than others. The same applies to the theme "motivation". Furthermore, there is a strong research trend in the "framework" theme with "research-trends" and "computer". The data obtained in this period indicate that the most relevant studies focused on the use of information and communication technologies and their pedagogical application, on the acceptance of pedagogical technological resources by the agents involved in the teaching and learning processes, on the design of technological instruments applied to the educational field, and on the motivation of students in the training processes in which information and communication technologies were used. In addition, in this period, it is necessary to bear in mind the themes "English" and "knowledge", given that their location in the diagram places them as unknown themes. In other words, they may be the next driving themes of AJET (Figure 8). 

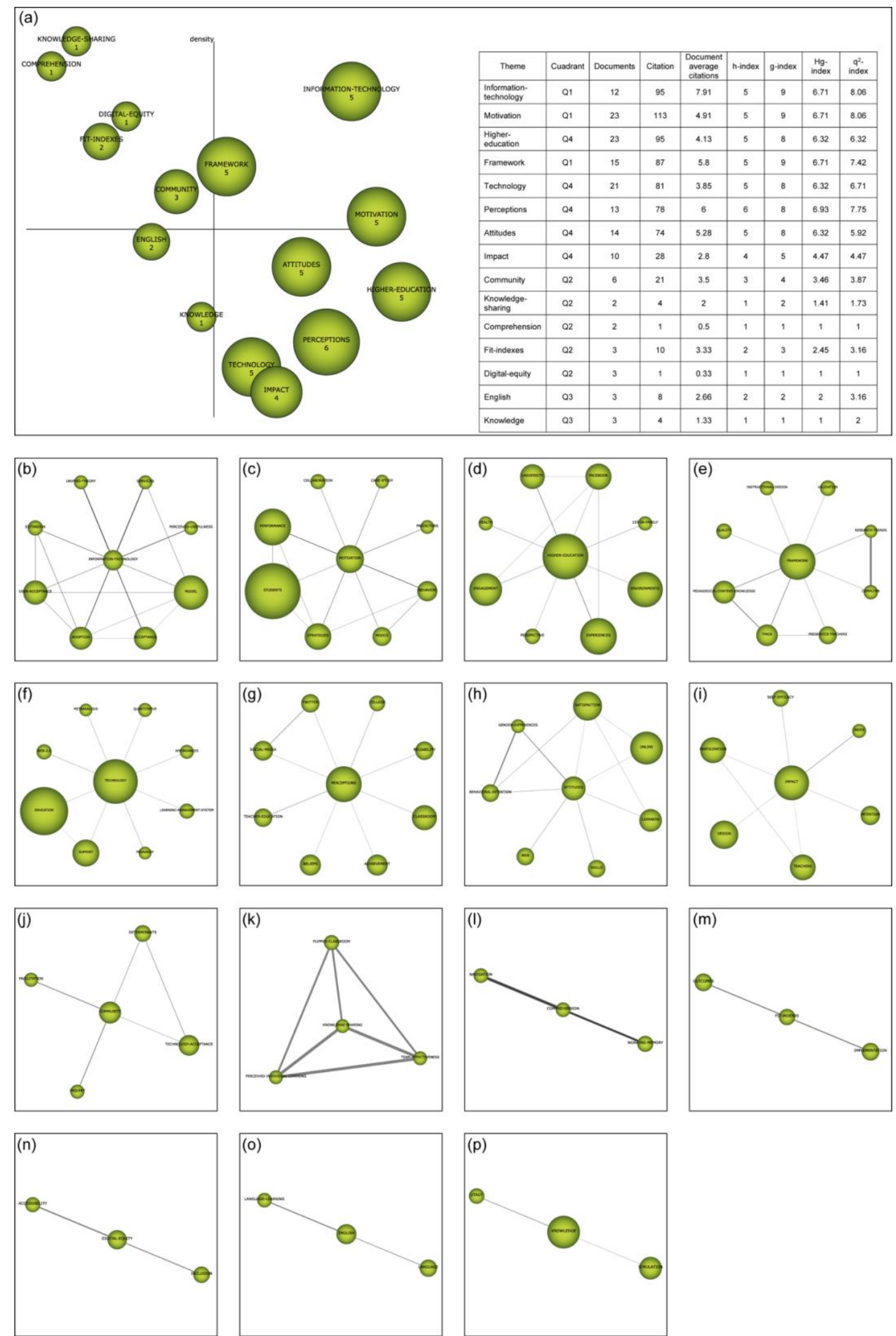

Figure 8. (a) Strategic diagram (h-index) and performance from 2017 to 2020. Themes are shown as follows: (b) "information-technology"; (c) "motivation"; (d) "higher-education"; (e) "framework"; (f) "technology"; (g) "perceptions"; (h) "attitudes"; (i) "impact"; (j) "community"; (k) "knowledge-sharing"; (1) "comprehension"; (m) "fit-indexes"; (n) "digital-equity"; (o) "English"; (p) "knowledge". 
The data represented in Figures 6, 7 and 8 are plotted in Table 4. It shows the position in the diagram and the values of centrality and density. In this case, it can be seen that only one theme was repeated in the three established time periods - "knowledge". Therefore, it can be considered the common thread of the research developed during all scientific production in AJET.

Table 4

Principal research themes from 2007 to 2020

\begin{tabular}{|c|c|c|c|}
\hline & P1 (2007-2011) & P2 (2012-2016) & P3 (2017-2020) \\
\hline Environments & Q1 (25.1/69.19) & & \\
\hline Attitudes & Q1 (43.13/29.56) & & Q4 (24.94/13.03) \\
\hline Knowledge & Q1 (28.75/15.83) & Q4 (67/10.21) & Q3 (12.77/6.12) \\
\hline Strategies & Q2 (23.61/16.71) & & \\
\hline Students & Q3 (24.11/7.42) & & \\
\hline Design & Q1 (24.7/12.73) & Q2 (44.22/18.85) & \\
\hline Teachers & Q4 (36.68/9.58) & Q2 (43.24/20.28) & \\
\hline Technology & Q3 $(26.61 / 2.07)$ & & \\
\hline Lectures & Q3 (1.98/11.11) & & \\
\hline User-acceptance & & Q1 (70.48/60.4) & \\
\hline Cognitive-load & & Q2 (36.93/35.65) & \\
\hline Reflection & & Q2 (45.53/26.67) & \\
\hline Styles & & Q1 (52.14/18.78) & \\
\hline Credibility & & Q1 (59.07/21.45) & \\
\hline Pedagogy & & Q2-Q3 (33.54/18.11) & \\
\hline ICT & & Q1 (49.84/29.56) & \\
\hline Higher-education & & Q3-Q4 (46.33/8.57) & Q4 (50.06/8.7) \\
\hline Motivation & & Q4 (63.75/7.99) & Q1 (45.45/16.69) \\
\hline Acceptance & & Q4 (55.25/5.44) & \\
\hline University & & Q3 (34.17/7.96) & \\
\hline Model & & Q4 (59.51/2.12) & \\
\hline Reality & & Q3 (17.53/12.5) & \\
\hline Information-technology & & & Q1 (40.7/30.49) \\
\hline Framework & & & Q1 (15.83/19.66) \\
\hline Technology & & & Q4 (16.19/4.77) \\
\hline Perceptions & & & Q4 (31.05/6.08) \\
\hline Impact & & & Q4 (21.79/4.2) \\
\hline Community & & & Q2 (11.35/16.79) \\
\hline Knowledge-sharing & & & Q2 $(0.78 / 125)$ \\
\hline Comprehension & & & Q2 (0.00/77.78) \\
\hline Fit-indexes & & & Q2 (1.3/22.22) \\
\hline Digital-equity & & & Q2 (1.31/22.22) \\
\hline English & & & Q3 (1.39/16.67) \\
\hline
\end{tabular}

Finally, the thematic evolution, represented in Figure 9, indicates the relationship between the themes of the continuous time periods. The connection established is based on Jaccard's index, and it happens when two themes share common keywords and/or themes. When the number of keywords and/or themes between the two themes is higher, the thickness of the represented line increases. The type of line represents whether the connection between themes is a keyword or a theme connection. The dashed line represents keywords, considered non-conceptual. The solid line represents themes, considered as conceptual. The data achieved in the analysis indicate that there is no conceptual gap, since there is one theme that is repeated in all periods - "knowledge". This does not mean that it is the most representative line of research in AJET. In this case, the most representative line in AJET's scientific production is "teachers-pedagogy-technology", together with three other research lines that can be considered relevant in AJET - "attitudes-user_acceptanceinformation_technology", "design-model-attitudes" and "design-model-information_technology". In addition, there are other lines of research that can be considered secondary. This means that the studies focused on these topics are more relevant in the scientific field, given that they are the most cited keywords. This suggests that authors with similar lines of research look to AJET in order to develop their studies. The resulting analysis shows that there are more conceptual than non-conceptual connections, which indicates that the studies are closely related to each other. 


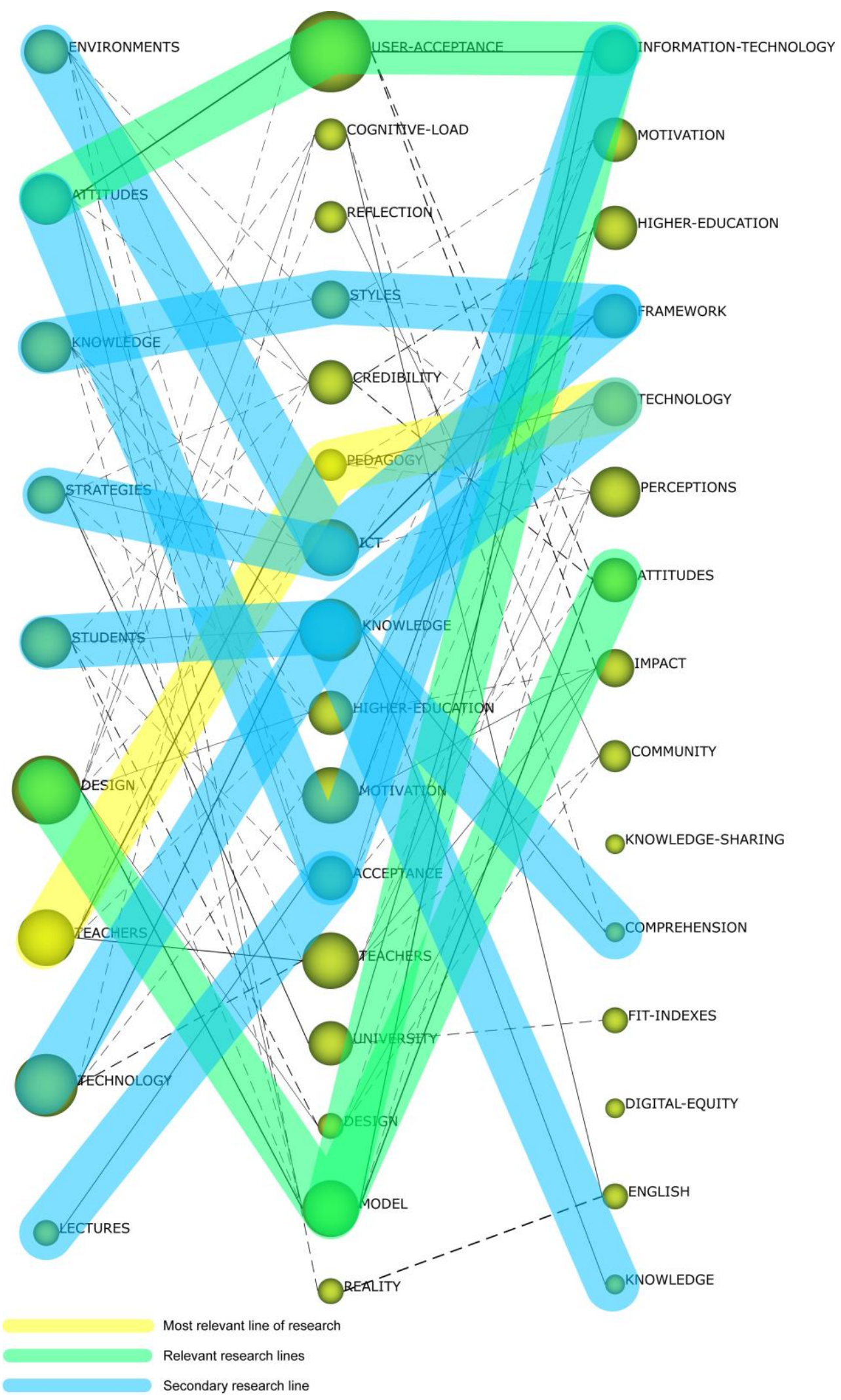

Figure 9. Thematic evolution by h-index 


\section{Authors}

In relation to authors, Pizzica, Kuo, and Shadiev are the most relevant, taking into account the bibliometric indicators, in AJET. This is due to their position in Figure 10. Similarly, Heinrich and Voogt, who may tend to disappear or become the next relevant authors in AJET, should be taken into consideration. The number of collaborations between the authors is relatively low, except for Gosper (Figure 9b) and Tsai (Figure 9c), whose collaborations with other authors usually number more than 4 . If the h-index is taken into account, Tsai and Voogt stand out, with h-index values of 7 and 6 respectively.
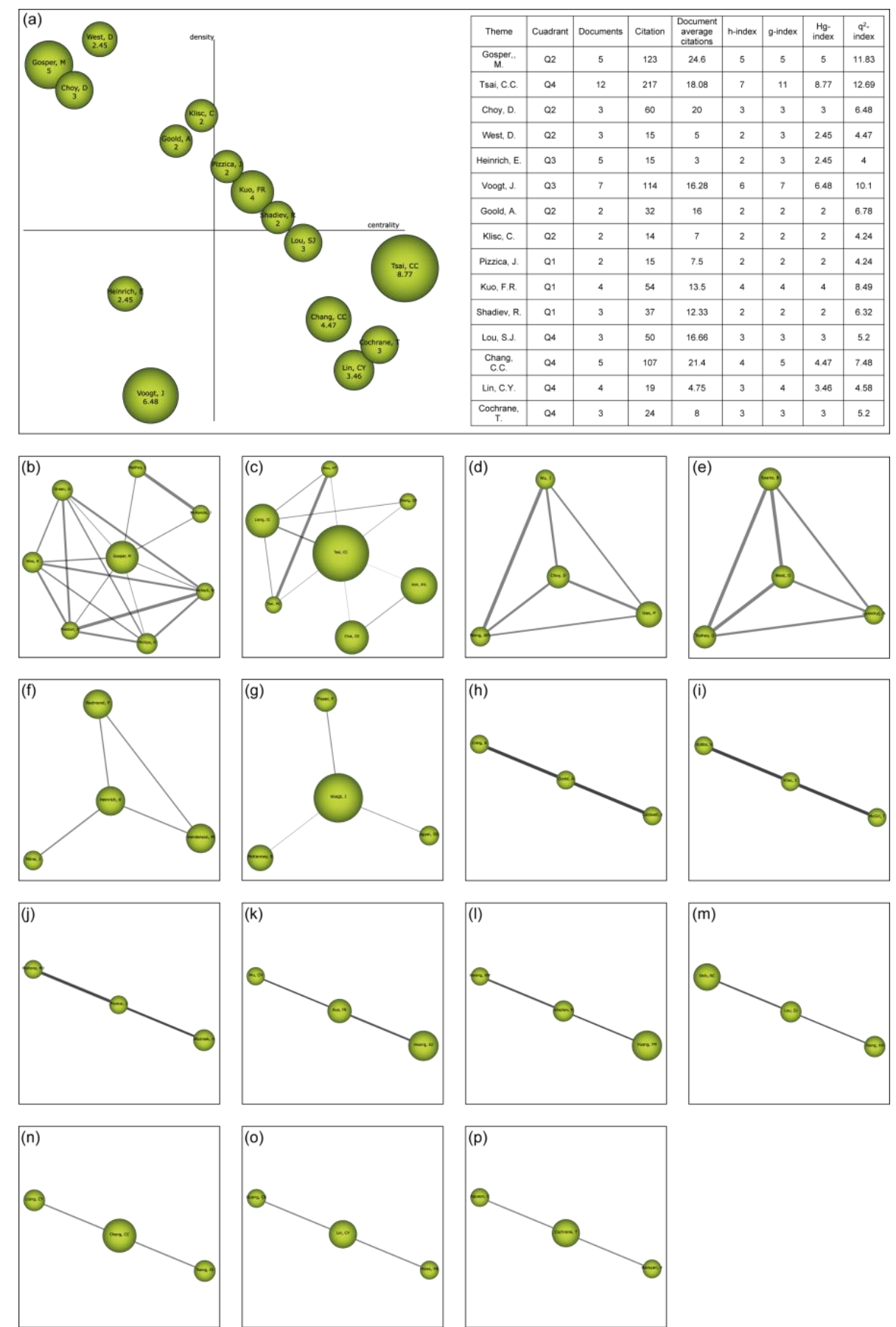

Figure 10. (a) Strategic diagram of authors (h-index) and performance from 2007 to 2020. (b) Gosper, M.; (c) Tsai, C. C.; (d) Choy, D.; (e) West, D.; (f) Heinrich, E.; (g) Voogt, J.; (h) Goold, A.; (i) Klisc, C.; (j) Pizzica, J.; (k) Kuo, F. R.; (l) Shadiev, R. ;(m) Los, S. J.; (n) Chang, C. C.; (o) Lin, C. Y.; (p) Cochrane, T. 


\section{Discussion}

To carry out a holistic review of research in educational technology, it is necessary to highlight the importance of AJET, one of the most influential journals in this field of investigation. The bibliometric analysis based on the scientific mapping of co-words carried out to determine its scientific evolution has allowed us to determine a compendium of relevant aspects.

In the first place, a high percentage of coincidence was found between the established time periods, configured in an equitable and tripartite way, with a range of 4-5 years, which reflects a line of research clearly established in the journal. Likewise, the number of keywords increases over the time period, which evidences a greater use of keywords by authors in AJET.

Regarding the findings related to the different temporal divisions, starting with the first period (2007-2011), we were able to verify that the theme "design" had the highest bibliometric value, followed by "environments", "attitudes", "knowledge" and "design". This trend reflects that the investigations of this period within AJET were focused on learning environments, the attitudes of the students in the application and use of the technological resources during the teaching and learning processes, the knowledge acquired by the students themselves while using technological resources and the design of training processes in which technological resources were applied. The thematic analysis addressed by Bond et al. (2019) investigated the evolution of thematic focuses from a conceptual map analysis with Leximancer and based on co-occurrence, highlighting the thematic importance of the growth of interactive learning and the evolution of distance education. However, our study carried out a co-word analysis for general maps with nodes that reveal the performance and location of various conceptual subdomains. Chen, Zou, and Xie (2020) have already reflected the existence of focuses of interest that can be transversely framed in these results, such as "learning experience" and "online learning" as key elements in the development of technopedagogy. Furthermore, bringing together the annual results obtained by Chen, Zou, Cheng et al. (2020) during the period of analysis, they found more specific centres of interest related to "context and collaborative learning", "online / web-based learning", and "experiments and methodologies", observing a growing context of experimentation and search for new methodologies based on techno-pedagogy.

Regarding the second period (2012-2016), we found that the topic with the highest bibliometric value is "user-acceptance", followed by other driving topics such as "user-acceptance", "ICT", "credibility", and "styles". This trend reflects that the investigations of this period were oriented towards the acceptance of students and teachers in the use of ICT in training processes, the analysis of possible gender differences in the use of techno-pedagogical resources, the pedagogical training of teachers in the use and application of technological resources during teaching, the credibility of the devices and applications used and the pedagogical methods used by teachers based on techno-pedagogy. For their part, these results coincide with the analysis by Chen, Zou and Xie (2020), who identified "information technology" and "communication technology" as centres of interest, in an evident generalisation of the incorporation of ICT. Chen, Zou, Cheng et al. (2020) obtained specific centres of interest such as "blended learning", "experiments and methodologies", and "context and collaborative learning", observing an even greater use of face-to-face combined with online learning alternatives. These results are related to those found by Bond et al. (2019), which determined a special importance to the centres of interest related to the use of mobile devices as well as collaborative and analytical learning for this period.

Regarding the third period (2017-2020), we observed that the topic with the highest bibliometric value was "perceptions", followed by other topics such as "information-technology", "framework", and "motivation". There was a trend in which research focused on the use of ICT and its pedagogical application, on the acceptance of pedagogical technological resources by the protagonists of the training process, on the design of instruments technologies applied to the educational field and on the motivation of students towards the use of ICT. Along these lines, we also observed that, within this last period, there was a growing trend in thematic centres related to "English" and "knowledge" - two topics that could be especially relevant in the coming years of AJET. Chen, Zou, Cheng et al. (2020) found similar centres of interest regarding "learning experience", an increasingly recurring element in new didactic proposals based on technology. For their part, Chen, Zou, Cheng et al. (2020) found that the centres of interest revolved around more specific concepts, such as "e-learning and policy", "multimedia and data-driven studies", "experiments and methodologies", and "blended learning", observing a more marked trend towards the exclusivity of online learning compared to other forms of combined techno-pedagogy. The results obtained in this period (2017- 
2020) agree with the lines of interest analysed on cross-related issues. Authors such as Kali et al. (2018) have already anticipated the potential of extending the training process outside the classroom, provided that it is complemented with the use of technology. Regarding the use of the student as a transversal element to the centres of interest, Vosinakis et al. (2018) and Nel (2017) presented interesting results regarding the importance of developing methods and tools that use collaborative methods in which students have their own voice in the pedagogical transformation generated by educational technology.

The "knowledge" theme was systematically repeated in all periods. This topic presents an evolution at a temporal level, focusing at first on aspects related to computer games and learning styles, later on other thematic centres related to students, learning environments and instructional processes and finally on quality and learning environments.

Likewise, it is pertinent to highlight that the most representative line in AJET's scientific production is "teachers-pedagogy-technology". Studies focused on this typology of topics are more relevant in the scientific field, since they are the most cited keywords. In this case, authors with similar lines of research look to AJET in order to develop their studies. This last question, together with the greater presence of conceptual rather than non-conceptual connections, allows us to verify that the investigations are closely related to each other.

In relation to the results obtained in terms of trends in educational technology, it is evident that, in the last period analysed, markedly promising and updated trends have not yet been established. This does not mean that the most cutting-edge and pioneering sectors of educational technology have not been able to produce valuable research within AJET. However, they do represent an important factor to take into account as essential future topics that the scientific community needs to continue studying. In recent years, one of the most influential innovations of educational technology has been the application of artificial intelligence in teaching and learning processes (Moreno-Guerrero et al., 2020). Studies related to its application and its possible gaps within the educational landscape have been fundamental (Chen, Xie et al., 2020), as well as future visions, challenges and new roles for its optimal implementation in education (Hwang et al., 2020). Another of the technological resources applied in teaching and learning processes is Arduino (https://www.arduino.cc/), the inclusion of which in training processes is relatively recent. This resource is nowadays related to computational thinking (López-Belmonte et al., 2020). There are also other important resources within the latest innovations in educational technology, such as the implementation of augmented reality as a catalyst for student motivation (Garzón et al., 2020; Hanid et al., 2020; Pochtoviuk et al., 2020) and the use of educational apps for mobile devices that can expand the limits of the virtual classroom, the face-to-face classroom and the learning experience itself (Blilat \& Ibriz, 2020; Tamtama, 2020). Along these lines, in recent years, many educational projects related to revitalising the virtual classroom based on new digital video platforms (Basith \& Syafi'i, 2020) and even projects based on the effect of specific apps based on social interactions (Cassel, 2021; Gulati et al., 2020) have also appeared. Another aspect related to educational technology is TPACK and the focus on the integration of technological resources and the analysis of student perception (Soler-Costa et al., 2021). Likewise, within the potentialities of technological evolution, the implementation of educational big data tools in recent years as a means of collecting relevant information from the instructional process to identify its weaknesses, strengths and opportunities is also a fundamental area (Fischer et al., 2020; Ruiz-Palmero et al, 2020). All these pioneering tools of educational technology have experienced enormous growth in recent years, but there is still significant scope to continue researching their potential and to configure new forms of optimisation.

In the results obtained in this study, the centers of interest are related to the attitudes and perceptions of the techno-pedagogical users instead of being related to types of educational tools and resources. In the last period analysed, they are constituted as topics and trends on the rise, but overshadowed by other, more general themes related to acceptance, information, user attitudes, the design of techno-pedagogical models, and the role of teachers in research on pedagogical technology. We hope that a future analysis of co-words on the state of the art in educational technology will shed light on this issue and allow a greater level of prominence for all these pioneering and avant-garde elements of educational technology. 


\section{Theoretical and practical implications}

This study continues the research path of other predecessor investigations in which the contributions collected in the WoS database for AJET were analysed from a bibliometric perspective. This analysis contributes to generating various practical and theoretical implications for the scientific community in general and for the followers of educational technologies in particular.

Regarding theoretical implications, this research establishes a contextual framework that reflects the trends of recent research in educational technology within AJET. This trend contributes to the orientation of researchers to address the topics of educational technology of greatest interest in recent years. Likewise, it also highlights the main research fields that still need a significant boost from new publications. Moreover, the analysis of bibliometric indicators carried out in this study allows researchers in educational technology to obtain a valuable information concerning the main authors in this field of research, the most cited works, the media, the areas of research, the most used languages and the reference institutions.

Research in AJET on educational technology generates interesting practical implications for the educational community. Analysing these research trends allows for increased knowledge and understanding about its pedagogical potential, as well as how teachers and students perceive the integration of educational technology in the learning process. Likewise, this investigation makes it possible to highlight the main ways in which educational technology has been integrated at a methodological level, revealing the main pedagogical trends that accompany the training approach complemented or led by ICT. In short, the main lines of research are highlighted in order to continue developing educational technologies and their inclusion in the classroom.

Research in educational technology has gained special relevance today as a consequence of the pandemic caused by COVID-19, which has affected the teaching and learning processes and has modified the spaces and means to carry out training. In this sense, educational technology has acquired value for teaching performance (Moreno-Guerrero et al., 2021). Therefore, this study serves as a knowledge base for establishing the state of the question at a time when technology favours the creation of new channels and resources for carrying out instruction.

Based on the trend results obtained in this study, a set of future lines of research related to educational technology are proposed below. First of all, the techno-pedagogical sector will continue to grow for decades to come. Based on the centres of interest in terms of "credibility", "reflection" and "motives" within research on educational technology, it would be interesting to continue researching the training of teachers in innovative and emerging technologies within the most pioneering and avant-garde educational environment. Training teachers in all educational stages is a fundamental element in effective teaching and learning process. The digital competence of teachers and students in techno-pedagogical innovations is the true basis of progress and optimisation of technology-led teaching. Furthermore, within the focus of interest around "digital equity", research related to the analysis of the digital divide continues to be necessary for all the protagonists of the educational process. Being aware of the digital gaps in the teaching community is essential, but it is also important to identify those gaps in students and within the family and domestic environment. It is essential to examine programs that have tried to solve the gaps in access, use, and quality of use, to verify their effectiveness, and to continue investigating new foci and centres of action in which digital equity is not guaranteed. It is vital to continue researching mechanisms that can solve the problems of technology access and use, taking advantage of the potential that educational technology itself offers. Finally, within the focus of interest around "user acceptance", it is important to investigate the different possible ways of applying the latest technological advances and how they could be applied to the educational landscape in an effective way. Along these lines, researchers should continue to analyse the different applications of big data tools, the use of augmented reality as a motivating element, the design and implementation of specific mobile applications by teachers and students themselves, and the use of cognitive artificial intelligence and eye tracking to determine the behavior of students during virtual or face-to-face classes. 


\section{Limitations of the study}

The main limitation of this study corresponds to the data cleaning process within the WoS database. Frequently, the extraction of information enables the detection of duplications of documents, which makes a detailed analysis of dumped data necessary. Likewise, both the time periods and the research parameters are set based on the criteria of the researchers, which entails a minimum of subjectivity, despite being carried out in a coherent and cohesive manner, seeking to show the results obtained in an optimal way. However, it is evident that carrying out an analysis of the scientific production of a journal confines its interest to the journal itself. This type of analysis has a high level of precision and specificity, which cancels the possibility of extrapolating the data obtained by other investigations, due to the uniqueness of the object of study. This type of study with adequate periodicity allows us to understand the evolution of research in educational technology in general, and of AJET's own research in particular.

\section{Conclusions}

This research entailed an analysis of the scientific production of AJET to increase the scientific literature in the field of educational technology. Using a bibliometric approach of scientific co-word mapping allowed us to identify journal production indicators and to understand the development of its publications at a dynamic and structural level. This type of analysis is necessary for prestigious journals with a positive impact factor within the JCR and Scopus, among other indexes. From the manuscripts collected within the WoS database, we found that AJET compiles studies and research with similar content, with an intense thematic correlation force, with the concept of "knowledge" being the common thread from 2007 to 2020. Despite this, the line of research with the greatest relevance is "teachers-pedagogy-technology", with a high index of representation within the journal. At the same time, we noted a progressive evolution of studies published in the journal: the first phase focused on settlement in the design and implementation of educational technology in learning environments, the second phase focused on greater predominance of the enrichment of technology and its acceptance within the teaching and learning processes, and the final stage focused on the perception of the protagonists of the training process during the implementation of learning contexts featuring technology.

\section{Acknowledgements}

This study has been funded by the I+D+i project: Active methodologies for learning through technological resources for the development of society; code: CNT 4315.

\section{References}

Anta-Cabreros, C. (2008). Análisis bibliométrico de la inveón educativa divulgada en publicaciones periódicas españolas entre 1990-2002 [Bibliometric analysis of educational research disseminated in Spanish journals between 1990 and 2002]. Revista Electrónica de Investigación Educativa, 10(1), 117. https://redie.uabc.mx/redie/article/view/185

Ariza, T., \& Quevedo-Blasco, R. (2013). Análisis bibliométrico de la Revista de Investigación Educativa (2000-2012) [Bibliometri analysis of the Revista de Investigación Educativa (2000-2012)]. Revista de Investigación Educativa, 31(1), 31-52. https://doi.org/10.6018/rie.31.1.160321

Basith, A., \& Syafi'i, A. (2020). Instagram as media in teaching writing recount text for senior high school students. SALEE: Study of Applied Linguistics and English Education, 1(1), 11-20. https://doi.org/10.35961/salee.v1i01.66

Blilat, A., \& Ibriz, A. (2020). Design and implementation of P2P based mobile app for collaborative learning in higher education. International Association of Online Engineering, 14(7), 115-132. https://doi.org/10.3991/ijim.v14i07.13167

Bond, M. (2018). Helping doctoral students crack the publication code: An evaluation and content analysis of the Australasian Journal of Educational Technology. Australasian Journal of Educational Technology, 34(5), 167-181. https://doi.org/10.14742/ajet.4363

Bond, M., \& Buntins, K. (2018). An analysis of the Australasian Journal of Educational Technology 2013-2017. Australasian Journal of Educational Technology, 34(4), 168-183. https://doi.org/10.14742/ajet.4359 
Bond, M., Zawacki-Richter, O., \& Nichols, M. (2019). Revisiting five decades of educational technology research: A content and authorship analysis of the British Journal of Educational Technology. British Journal of Educational Technology, 50(1), 12-63. https://doi.org/10.1111/bjet.12730

Bueno, Á., \& Fernández, A. (2003). Análisis cientimétrico de la productividad en la Revista de Investigación Educativa (1983-2000) [Scientimetric analysis of productivity in the Journal of Educational Research]. Revista de Investigación Educativa, 21(2), 507-532. https://bit.ly/3d8oly3

Carmona-Serrano, N., Moreno-Guerrero, A.-J., Marín-Marín, J.-A., \& López-Belmonte, J. (2021). Evolution of the autism literature and the influence of parents: A scientific mapping in Web of Science. Brain Sciences, 11(1), 1-16. https://doi.org/10.3390/brainsci11010074

Cascón-Katchadourian, J., Moral-Munoz, J. A., Liao, H., \& Cobo, M. J. (2020). Análisis bibliométrico de la Revista Española de Documentación Científica desde su inclusión en la Web of Science (20082018) [Bibliometric analysis of the Spanish Journal of Scientific Documentation since its inclusion in the Web of Science (2008-2018)]. Revista Española De Documentación Científica, 43(3), 1-16. https://doi.org/10.3989/redc.2020.3.1690

Cassel, A. (2021). Twitch for higher education marketing and communications: Creating a presence in the gaming world. Journal of Education Advancement \& Marketing, 5(4), 323-334. https://doi.org/10.3991/ijep.v10i1.11551

Chen, X., Chen, B., Zhang, C., \& Hao, T. (2017). Discovering the recent research in natural language processing field based on a statistical approach. In T. C. Huang, R. Lau, Y. M. Huang, M. Spaniol, \& C. H. Yuen (Eds.), Lecture notes in computer science, Vol. 10676. Emerging technologies for education (pp. 507-517). Springer. https://doi.org/10.1007/978-3-319-71084-6_60

Chen, X., Hao, J., Chen, J., Hua, S., \& Hao T. (2018). A Bibliometric Analysis of the Research Status of the Technology Enhanced Language Learning. In T. Hao, W. Chen, H. Xie, W. Nadee, \& R. Lau (Eds.), Lecture notes in computer science, Vol. 11284. Emerging technologies for education (pp. 169179). Springer. https://doi.org/10.1007/978-3-030-03580-8_18

Chen, X., Liu, Z., Wei, L., Yan, J., Hao, T., \& Ding, R. (2018). A comparative quantitative study of utilizing artificial intelligence on electronic health records in the USA and China during 2008-2017. BMC Medical Informatics and Decision Making, 18(S5), 55-127. https://doi.org/10.1186/s12911$\underline{018-0692-9}$

Chen, X., Lun, Y., Yan, J., Hao, T., \& Weng, H. (2019). Discovering thematic change and evolution of utilizing social media for healthcare research. BMC Medical Informatics And Decision Making, 19(S2), 39-53. https://doi.org/10.1186/s12911-019-0757-4

Chen, X., Weng H., \& Hao T. (2017). A data-driven approach for discovering the recent research status of diabetes in China. In S. Siuly, Z. Huang, U. Aickelin, R. Zhou, H. Wang, Y. Zhang, \& S. Klimenko (Eds.), Lecture notes in computer science, Vol. 10594. Health information science (pp. 89-101). Springer. https://doi.org/10.1007/978-3-319-69182-4_10

Chen, X., Xie, H., Zou, D., \& Hwang, G. J. (2020). Application and theory gaps during the rise of artificial intelligence in education. Computers and Education: Artificial Intelligence, 1, 1-20. https://doi.org/10.1016/j.caeai.2020.100002

Chen, X., Zou, D., Cheng, G., \& Xie, H. (2020). Detecting latent topics and trends in educational technologies over four decades using structural topic modeling: A retrospective of all volumes of Computers \& Education. Computers \& Education, 151, 1-21. https://doi.org/10.1016/j.compedu.2020.103855

Chen, X., Zou, D., \& Xie, H. (2020). Fifty years of British Journal of Educational Technology: A topic modeling based bibliometric perspective. British Journal of Educational Technology, 51(3), 692-708. https://doi.org/10.1111/bjet.12907

Cobo, M. J., López, A. G., Herrera, E., \& Herrera, F. (2011). Science mapping software tools: Review, analysis, and cooperative study among tools. Journal of the American Society for Information Science and Technology, 62(7), 1382-1402. https://doi.org/doi:10.1002/asi.21525

Donthu, N., Kumar, S., Pandey, N., \& Gupta, P. (2021). Forty years of the International Journal of Information Management: A bibliometric analysis. International Journal of Information Management, 57, 1-22. https://doi.org/10.1016/j.ijinfomgt.2020.102307

Elgort, I., Smith, A. G., \& Toland, J. (2008). Is wiki an effective platform for group course work? Australasian Journal of Educational Technology, 24(2), 195-210. https://doi.org/10.14742/ajet.1222

Fischer, C., Pardos, Z. A., Baker, R. S., Williams, J. J., Smyth, P., Yu, R., \& Warschauer, M. (2020). Mining big data in education: Affordances and challenges. Review of Research in Education, 44(1), 130-160. https://doi.org/10.3102/0091732X20903304 
Garzón, J., Baldiris, S., Gutiérrez, J., \& Pavón, J. (2020). How do pedagogical approaches affect the impact of augmented reality on education? A meta-analysis and research synthesis. Educational Research Review, 31, 1-19. https://doi.org/10.1016/j.edurev.2020.100334

Gulati, R. R., Reid, H., \& Gill, M. (2020). Instagram for peer teaching: Opportunity and challenge. Education for Primary Care, 31(6), 382-384. https://doi.org/10.1080/14739879.2020.1811163

Hanid, M. F., Said, M. N., \& Yahaya, N. (2020). Learning strategies using augmented reality technology in education: Meta-analysis. Universal Journal of Educational Research, 8(5), 51-56. https://doi.org/10.13189/ujer.2020.081908

Hirsch, J. E. (2005). An index to quantify an individual's scientific research output. Proceedings of the National academy of Sciences, 102(46), 16569-16572. https://doi.org/10.1073/pnas.0507655102

Hwang, G. J., Xie, H., Wah, B. W., \& Gašević, D. (2020). Vision, challenges, roles and research issues of artificial intelligence in education. Computers and Education: Artificial Intelligence, 1, 1-5. https://doi.org/10.1016/j.caeai.2020.100001

Irwin, C., Ball, L., Desbrow, B., \& Leveritt, M. (2012). Students' perceptions of using Facebook as an interactive learning resource at university. Australasian Journal of Educational Technology, 28(7), 1221-1232. https://doi.org/10.14742/ajet.798

Jurado de los Santos, P., Moreno-Guerrero, A., Marín-Marín, J., \& Soler Costa, R. (2020). The term equity in education: A literature review with scientific mapping in Web of Science. International Journal of Environmental Research and Public Health, 17(10), 1-17. https://doi.org/10.3390/ijerph17103526

Kali, Y., Levy, K. S., Levin-Peled, R., \& Tal, T. (2018). Supporting outdoor inquiry learning (SOIL): Teachers as designers of mobile-assisted seamless learning. British Journal of Educational Technology, 49(6), 1145-1161. https://doi.org/10.1111/bjet.12698

Kennedy, G. E., Judd, T. S., Churchward, A., Gray, K., \& Krause, K. L. (2008). First year students' experiences with technology: Are they really digital natives? Australasian Journal of Educational Technology, 24(1), 108-122. https://doi.org/10.14742/ajet.1233

Laufer, M. (2007). La cultura de la publicación científica (I) [The culture of scientific publication (I)]. Interciencia, 32(8), 501-503. https://www.redalyc.org/articulo.oa?id=33932801

López-Belmonte, J., Marín-Marín, J. A., Soler-Costa, R., \& Moreno-Guerrero, A. J. (2020). Arduino advances in Web of Science: A scientific mapping of literary production. IEEE Access, 8, 128674 128682. https://doi.org/10.1109/ACCESS.2020.3008572

López-Belmonte, J., Moreno-Guerrero, A. J., López-Núñez, J. A., \& Pozo-Sánchez, S. (2019). Analysis of the productive, structural, and dynamic development of augmented reality in higher education research on the Web of Science. Applied Sciences, 9(24), 1-21. https://doi.org/10.3390/app9245306

López-Belmonte, J., Segura-Robles, A., Moreno-Guerrero, A. J., \& Parra-González, M. E. (2021). Projection of e-learning in higher education: A study of its scientific production in Web of Science. European Journal of Investigation in Health, Psychology and Education, 11(1), $20-32$. https://doi.org/10.3390/ejihpe11010003

López-Robles, J. R., Otegi-Olaso, J. R., Porto, I., \& Cobo, M. J. (2019). 30 years of intelligence models in management and business: A bibliometric review. International Journal of Information Management, 48, 22-38. https://doi.org/10.1016/j.ijinfomgt.2019.01.013

Mac Fadden, I., Santana, M., Vázquez-Cano, E., \& López-Meneses, E. (2020). A science mapping analysis of 'marginality, stigmatization and social cohesion' in WoS (1963-2019). Quality \& Quantity, 1-19. https://doi.org/10.1007/s11135-020-01004-7

Martínez, M. A., Cobo, M. J., Herrera, M., \& Herrera, E. (2015). Analyzing the scientific evolution of social work using science mapping. Research on Social Work Practice, 25(2), 257-277. https://doi.org/10.1177/1049731514522101

McGarr, O. (2009). A review of podcasting in higher education: Its influence on the traditional lecture. Australasian Journal of Educational Technology, 25(3), 309-321. https://doi.org/10.14742/ajet.1136

McLoughlin, C., \& Lee, M. J. W. (2010). Personalised and self regulated learning in the Web 2.0 era: International exemplars of innovative pedagogy using social software. Australasian Journal of Educational Technology, 26(1), 28-43. https://doi.org/10.14742/ajet.1100

Moher, D., Shamseer, L., Clarke, M., Ghersi, D., Liberati, A., Petticrew, M., Shekelle, P., Stewart, L. A., \& PRISMA-P Group. (2015). Preferred reporting items for systematic review and meta-analysis protocols (PRISMA-P) 2015 statement. Systematic Reviews, 4(1), 1-9. https://doi.org/10.1186/20464053-4-1 
Montero-Díaz, J., Cobo, M.J., Gutiérrez-Salcedo, M., Segado-Boj, F., \& Herrera-Viedma, E. (2018). Mapeo científico de la Categoría «Comunicación» en WoS (1980-2013) [A science mapping analysis of ‘communication' WoS subject category (1980-2013)]. Comunicar, 26(55), 81-91. https://doi.org/10.3916/C55-2018-08

Moral-Muñoz, J. A., Herrera-Viedma, E., Santisteban-Espejo, A., \& Cobo, M. J. (2020). Software tools for conducting bibliometric analysis in science: An up-to-date review. Profesional de la Información, 29(1), 1-20. https://doi.org/10.3145/epi.2020.ene.03

Moreno-Guerrero, A. J., López-Belmonte, J., Marín-Marín, J. A., \& Soler-Costa, R. (2020). Scientific development of educational artificial intelligence in Web of Science. Future Internet, 12(8), 1-18. https://doi.org/10.3390/fi12080124

Moreno-Guerrero, A. J., Soler-Costa, R., Marín-Marín, J. A., \& López-Belmonte, J. (2021). Flipped learning y buenas prácticas docentes en educación secundaria [Flipped learning and good teaching practices in secondary education]. Comunicar, 68, 107-117. https://doi.org/10.3916/C68-2021-09

Morris, S., DeYong, C., Wu, Z., Salman, S., \& Yemenu, D. (2002). DIVA: A visualization system for exploring document databases for technology forecasting. Computers \& Industrial Engineering, 43(4), 841-862. https://doi.org/10.1016/s0360-8352(02)00143-2

Nel, L. (2017). Students as collaborators in creating meaningful learning experiences in technologyenhanced classrooms: An engaged scholarship approach. British Journal of Educational Technology, 48(5), 1131-1142. https://doi.org/10.1111/bjet.12549

Pérez-Matos, N. E. (2002). La bibliografía, bibliometría y las ciencias afines [Bibliography, bibliometrics and related sciences]. Acimed, 10(3), 1-16. http://scielo.sld.cu/scielo.php?script=sci_arttext\&pid=S1024-94352002000300001

Pochtoviuk, S. I., Vakaliuk, T. A., \& Pikilnyak, A. V. (2020). Possibilities of application of augmented reality in different branches of education. Educational Dimension, 54(2), 179-197. https://doi.org/10.2139/ssrn.3719845

Pritchard, A. (1969). Statistical bibliography; an interim bibliography. North-Western Polytechnic.

Ruiz-Palmero, J., Colomo-Magaña, E., Ríos-Ariza, J. M., \& Gómez-García, M. (2020). Big data in education: Perception of training advisors on its use in the educational system. Social Sciences, 9(4), 1-13. https://doi.org/10.3390/socsci9040053

Soler-Costa, R., Moreno-Guerrero, A. J., López-Belmonte, J., \& Marín-Marín, J. A. (2021). Co-word analysis and academic performance of the term TPACK in Web of Science. Sustainability, 13(3), 120. https://doi.org/10.3390/su13031481

Tamtama, G. I. W., Suryanto, P., \& Suyoto. (2020). Design of English vocabulary mobile apps using gamification: An Indonesian case study for kindergarten. International Journal of Engineering Pedagogy, 10(1), 150-162. https://doi.org/10.3991/ijep.v10i1.11551

Vosinakis, S., Anastassakis, G., \& Koutsabasis, P. (2018). Teaching and learning logic programming in virtual worlds using interactive microworld representations. British Journal of Educational Technology, 49(1), 30-44. https://doi.org/10.1111/bjet.12531

Corresponding author: Jesús López-Belmonte, jesuslopez@ugr.es

Copyright: Articles published in the Australasian Journal of Educational Technology (AJET) are available under Creative Commons Attribution Non-Commercial No Derivatives Licence (CC BY-NC-ND 4.0). Authors retain copyright in their work and grant AJET right of first publication under CC BY-NC-ND 4.0.

Please cite as: López-Belmonte, J., Moreno-Guerrero, A-J., Pozo-Sánchez, S., \& Marín-Marín, J-A. (2021). Co-word analysis and academic performance from the Australasian Journal of Educational Technology in Web of Science. Australasian Journal of Educational Technology, 37(6), 119-140. https://doi.org/10.14742/ajet.6940 